\title{
A SURVEY OF THE MAMMALS OCCURRING IN THE GOLDEN GATE HIGHLANDS NATIONAL PARK
}

I. L. RAUTENBACH

Transvaal Museum

P.O. Box 413

Pretoria

0001

Abstract - This paper reports on a survey of the mammals of the Golden Gate Highlands National Park, Republic of South Africa. Fifty-seven species are mentioned, the majority recorded through material or sight records. Those species which may occur in the Park, as deducted from their overall distribution ranges, or from other indirect observations such as spoor or droppings, are considered as well. Habitat preferences are mentioned wherever possible, and the conservation status and relocation histories of the antelope species are quoted.

\section{Introduction}

The main object of this study is to provide a checklist of mammals for the Golden Gate Highlands National Park, Republic of South Africa, but stems from an interest in the taxonomy and zoogeography of the mammals of southern Africa. These interests can only be successfully pursued through intensive and continuous collecting. When the late Dr. N. J. van der Merwe, and later his successor Dr. G. de Graaff, prompted myself and my predecessor $\mathrm{Mr}$ C. G. Coetzee to produce such a checklist for this Park, we obligingly agreed without hesitation.

This Park in the north eastern Orange Free State on the border of Lesotho, was proclaimed in 1963, primarily for its scenic beauty. Six farms were dispossessed, comprising a total area of 4792 ha of mountain sourveld (van Rensburg 1968). The Park constitutes the upper catchment area of the Little Caledon River, and varies in altitude from $1800 \mathrm{~m}$ at the riverbed to $3000 \mathrm{~m}$ at the peak of Rhebokkop. The watershed between the Orange-and Vaal River systems is at the eastern boundary of the Park.

The National Parks Board of Trustees, in agreeance with its conservation policy, subsequently reintroduced the game animals that long ago disappeared from the area as a result of human settlement and agricultural interests (Liebenberg 1964; Penzhorn 1971). For obvious reasons the Board could not reintroduce some of the 
former residents such as lion, wild dog, hippopotamus and elephant. Primarily as a result of pressing conservation problems in other national parks, very little research has thus far been conducted on the fauna and flora of the Golden Gate Highlands National Park. Roberts (1969) pioneered research within the Park by conducting a botanical survey.

\section{Material and Methods}

In aid of this survey, the area has been visited three times, i.e. for a ten-day period during July 1965, as well as two additional ten-day periods during May and November 1969. The species discussed in the text include not only those whose presence have been confirmed through sight or material records, but also those whose occurrence are suspected through circumstantial evidence such as general species range, or spoor and faeces encountered in the Park. This latter group comprises predominantly mammals in the medium-size range which migrate or wander mostly unnoticed over great distances.

Specimens of only those species still presenting taxonomic problems were collected, being without exception in the smallermammal species range. Specimens were procured through the normal mammal-collecting techniques, which need no elaboration here as it has been extensively described in the literature. Trapping was done predominantly in those area offering the best habitat. The animals collected were prepared as standard study-material and have been incorporated in the permanent collection of the Transvaal Museum.

\section{Results}

The following species have been noted to occur, or may occur in the Park:

Erinaceus frontalis Smith, 1831

Hedgehog

Krimpvarkie

Although as yet not recorded from the Park, it almost certainly occurs here, since suitable habitat is available, and since the Park falls within the known range of the species. It has been recorded from the nearby Reitz and Senekal districts (Lynch 1975).

Myosorex varius Smuts, 1832

Forest Shrew

Bos Skeerbek

A large series of 17 males and 21 females have been collected, mostly on the grassy slopes of Bakenkop. A few specimens were also procured in dense grass on the riverbanks near Wilgenhof. 
Although this species has never been recorded from the O.F.S., it is almost certain to occur in the Park, as it falls within the species range and affords suitable habitat. Faeces, presumably of this species, was found in old rock walls, but attempts at trapping animals were unsuccessful.

Crocidura cyanea Duvernoy, 1838

Reddish-Grey Musk Shrew Rooigrys Skeerbek

A single specimen was procured in dense grass along a stream.

Amblysomus hottentotus A. Smith, 1829

Four females were collected during November 1969 under willow trees on the banks of the Small Caledon River. At this locality this species coexists with the rodent mole (Cryptomys hottentotus Lesson, 1826) in the same area, albeit in separate tunnel systems. On the surface the tunnel systems of these two unrelated fossorial animals cannot be distinguished. The substrate was of a black clayish type.

Two of the females were reproductively active.

Chlorotalpa sclateri Broom, 1907

Sclater's Golden Mole

Sclaterse Kruipmol

No material has as yet been collected within the Park, but three specimens in the Transvaal Museum collection have been collected from the nearby Clocolan district (2827DC). The characteristic shallow subsurface tracks of this species have been found in the low-lying areas of the Park.

Pipistrellus kuhli Natterer, 1817

Kuhl's Pipistrelle

Kuhlse Vlermuis

Recorded by Lynch (1975) from areas adjacent to the Park. The species is as a consequence almost certain to occur within the boundaries of the Park.

Eptesicus capensis A. Smith, 1829

Cape Serotine

Kaapse Dakvlermuis

Lynch (op. cit.) recorded this species within $25 \mathrm{~km}$ east of Golden Gate, and it is therefore not unlikely that it will in time be recorded from within the Park.

Papio ursinus Kerr, 1792

Chacma Baboon

Kaapse Bobbejaan

A fairly large troop has regularly been observed in the Park on the mountain slopes and crests. 
A single specimen was collected during November 1969. Hares of the genus Lepus are not at all common in Golden Gate. Lynch (1975) unfortunately did not verify the identification of this specimen while extracting Transvaal Museum records for his paper, and consequently incorrectly cited it under Lepus capensis Linnaeus, 1758.

\section{Lepus capensis Linnaeus, $1758 \quad$ Cape Hare \\ Vlakhaas}

It is not impossible that this species is to be found at Golden Gate, but no material exists from the near vicinity of the Park to substantiate such a speculation. Lynch (1975) claims the presence of this species in the Park and vicinity, but apart from a misidentified specimen recorded, the remainder of his records are non-material. He did not state whether the latter are from roadkills or sightings. It is of course impossible to distinguish between $L$. capensis and $L$. saxatilis in the wild state.

Pronolagus rupestris A. Smith, 1834

Smith's Red Hare

Smith se Rooihaas

Two specimens, a male and a female, were collected in the hills behind Glen Reenen camp during November 1969. The female was lactating. Judging from the number of toilet-sites found, so characteristic of the genus, this species is relatively abundant in the Park. The measurement parameters quoted by Petter (1971) in his identification key are not clear, and as a consequence the key and taxonomic approach of Ellerman, Morrison-Scott and Hayman (1953) is followed here.

Cryptomys hottentotus Lesson, 1826

Common Mole Rat

Hotnot Grysmol

Three specimens were collected in the Park to date. This species occurs in the low-lying areas as well as on the higher platos and hillslopes, indicating a wider habitat tolerance than the golden moles.

Hystrix africaeaustralis Peters, 1852

Cape Porcupine

Ystervark

Although this species has never been observed during collecting trips, its presence has been confirmed by several quills found in the veld, particularly at the bases of rockfaces on the lower hillslopes.

Pedetes capensis Forster, 1778

Springhare

Springhaas

Springhares have never been observed during night-hunting operations, but they almost certainly occur here. Lynch (1975) reports sight records from the near vicinity of the Park. 
Although the vernacular name of this insectivorous rodent denotes its preferred habitat, it is also to be found in rocky places, as for instance the Golden Gate material. All three specimens were trapped amongst rock debris at the foot of the Sentinel. The only female in the series was pregnant upon collection during November; four foetuses, one in the left and three in the right uterus horn.

Aethomys namaquensis Smith, 1834

Namaqua Rock Rat

Namakwalandse Klipmuis

This is an abundant inhabitant of the rocky mountain slopes of Golden Gate.

Aethomys chrysophilus de Winton, 1897

African Bush Rat

Afrikaanse Bosrot

Not recorded through this project. Lynch (1975) claims its presence in the near vicinity of this Park, which entails a $100 \mathrm{~km}$ westwards extension of the known range as defined by Davis (1974). However, the streambanks lined with Ouhout Leucosidea sericea as found in the Park, do not appear to offer suitable habitat when compared with the bushveld conditions selected over the rest of the species range.

Leggada minutoides A. Smith, 1834

Dwarf Mouse

Dwergmuis

A series of four was collected in the long grass near the Brandwag camp.

Mus musculus Linnaeus, 1758

House mouse

Huismuis

A single specimen was procured in the non-white compound.

Praomys natalensis Smith, 1834

Multimammate mouse

Vaalveldmuis

A common rodent in the denser grass of low-lying areas.

Rattus rattus Linnaeus, 1758

House Rat

Huisrot

Several specimens were trapped in the living quarters of the bantu staff of the Park.

Rhabdomys pumilio Sparrman, 1784

\section{Striped mouse \\ Streepmuis}

A common rodent in the Park, especially in dense tall grass. According to Coetzee (in litt.), it was also found to construct its grassnests in old rockwalls up to almost a meter above ground level, which is a deviation from the normal behaviour. 
A single specimen was collected in long grass along the road near the Brandwag camp.

Dendromus mystacalis Heuglin, 1863

\section{Lesser Climbing Mouse \\ Kleiner Klimmuis}

Four specimens were collected, all from dense tall grass either along the road, the river or the base of a hill at Wilgenhof. One specimen had the remains of insects in its stomach. This is a new record for the Orange Free State as the result of a westwards range extention along the $29^{\circ}$ latitude.

Malacothrix typica Smith, 1834

\section{Large-Eared Mouse}

Grootoormuis

Recorded by Lynch (1975) in the Bethlehem/Kestell districts, near the Park.

Mystromys albicaudatus Smith, 1834

White-Tailed Rat

Witstertrot

As yet not recorded from the Park itself. It is essentially a grasslandplains species, but may in time prove to be a resident of Golden Gate as it has been recorded from the nearby districts (Davis 1974; Lynch 1975).

Tatera brantsi A. Smith, 1834

Highveld Gerbil

Hoëveldse Nagmuis

Several colonies were found in sandy patches of low-lying areas.

Otomys irroratus Brants, 1827

Vlei Rat

Vleirot

A common rodent of the grassy areas near water. Somewhat atypically, the species was also recorded on the lower hillslopes, especially where the ground is soggy at the bases of rocks. Coetzee collected two specimens with pure-white hindquarters in the Park during a Museum collecting trip in 1965. According to him (in litt.) this is the only instance of partial albinism known in this species south of Zaïre.

Note: Without examining the specimen, Lynch (1975) accepts as authentic the identity of an Otomys specimen from Golden Gate, housed in the TM collection, but misidentified as $O$. unisulcatus. The unfortunate result is that he plots the occurrence of $O$. unisulcatus at Golden Gate, some $200 \mathrm{~km}$ out of range (Davis 1974) in completely atypical habitat. I examined the specimen in question, and found it answers to the description of $O$. irroratus. Consequently Lynch's (1975) record of O. unisulcatus from Golden Gate is rejected here. 
This species certainly occurs in the Park, but unfortunaiely no substantiating material could as yet be collected. The typical Otomys faeces have, however, been found higher up on the mountain slopes in typical $O$. sloggetti habitat.

Vulpes chama A. Smith, 1833

\section{Silver Fox}

Silwervos

Not recorded during our visits, but as this is a widely distributed species in the Orange Free State, individuals will undoubtedly occur in the Park from time to time.

Canis mesomelas Schreber, 1775

Black-Backed Jackal

Rooijakkals

An individual was encountered during night-collecting operations.

Aonyx capensis Schinz, 1821

Cape Clawless Otter

Groototter

The spoor and characteristic droppings of this species was found along the river as well as at the big dam in the game camp.

Lutra maculicollis Lichtenstein, 1835

Spotted-Necked Otter

Klein-Otter

The presence of this species in the Park could as yet not be confirmed. Since it has been reported from the nearby districts (Lynch 1975), a resident population, or at least migrants through the Park, is very likely.

Ictonyx striatus Perry, 1810

Striped Polecat

Stinkmuishond

Individuals have been observed in the Park, but as yet none could be collected. A roadkill is reported by Coetzee (in litt.) on the main road near the Park entrance.

\section{Genetta trigrina tigrina Schreber, $1776 \quad$ Large-Spotted Genet \\ Grootkolmuskejaatkat}

Two specimens were live-trapped in the shrub along watercourses. After deliberation with C. G. Coetzee and J. Pringle (pers. comm.) these specimens were assigned to this subspecies, in difference to Lynch (1975) who recognizes only $G$. genetta Linnaeus, 1758 in this area and the rest of the Orange Free State. Consequently this constitutes a new record for this Province.

Cynictis penicillata G. Cuvier, 1829

Yellow Mongoose

Geelmeerkat

No specimens of this species were collected, but a colony to the east of the game camp has often been observed. 
Certainly the most common carnivore in the Park, and several were livetrapped of which two were prepared as specimens. They seem to prefer the wooded banks of the various streams flowing through the Park. A female collected during November was lactating.

Ichneumia albicauda G. Cuvier, 1829

White-Tailed Mongoose Witstertmuishond

Lynch (1975) reports this species from areas adjacent to Golden Gate. As the Park offers suitable habitat this animal may in time be shown to occur here as well.

\section{Atilax paludinosus G. Cuvier, $1777 \quad$ Marsh Mongoose \\ Kommetjiesgatmuishond}

The spoor and faeces of this animal was found, but it was not collected or seen during our visits.

\section{Proteles cristatus Spaarman, $1783 \quad$ Aardwolf \\ Maanhaarjakkals}

This species was never encountered, but spoor seen in the Park was probably that of this animal. The fact that the aardwolf is widely distributed in the Orange Free State renders it very likely to be present in the Park.

Felis caracal Schreber, 1776

Caracal

Rooikat

Spoor were found on several occasions, while a former ranger has seen a caracal in the Park.

Felis libyca Forster, 1780

Cape Wild Cat

Vaalboskat

Several of these animals were seen during night collecting trips, but unfortunately none were collected.

Procavia capensis Pallas, 1766

Cape Dassie

Klipdas

Three specimens were collected, of which one was heavily infected with lungworms. Dassies are particularly abundant in Golden Gate.

Equus burchelli Gray, 1824

$$
\begin{aligned}
& \text { Burchell's Zebra } \\
& \text { Bontkwagga }
\end{aligned}
$$

The Burchell's zebra were reintroduced from the Kruger National Park (Penzhorn 1971). The population has settled down well and is expanding (National Parks Board of Trustees Annual Report 49:1974/75). 
Phacochoerus aethiopicus Pallas, 1766

Warthog

Vlakvark

Reintroduced from the Hluhluwe Game Reserve (Penzhorn 1971), but the animals have apparently not adapted very well.

Syncerus caffer Sparrman, $1779 \quad$ Cape Buffalo

Kaapse Buffel

Reintroduced from the Addo Elephant National Park (Penzhorn 1971 ).

Taurotragus oryx Pallas, 1766

Eland

Reintroduced from the Kalahari Gemsbok National Park, Addo Elephant National Park, and the Willem Pretorius Game Reserve (O.F.S.) (Penzhorn 1971). The population is slowly expanding (National Parks Board of Trustees Annual Report 49).

Redunca arundinum Boddaert, $1785 \quad$ Reedbuck

Rietbok

Reintroduced from Northam (Tvl.) (Penzhorn 1971), but these animals are adapting poorly to their new environment.

Redunca fulvorufula Afzelius, 1815

Mountain Reedbuck

Rooiribbok

Reintroduced from Lückhoff (O.F.S.) (Penzhorn 1971). Population numbers have not increased significantly since 1971 (National Parks Board of Trustees Annual Reports 46-48).

Alcelaphus buselaphus caama G. Cuvier, 1804 Cape Hartebeest

Rooihartbees

Reintroduced from the Addo Elephant National Park, Kalahari Gemsbok National Park, Willem Pretorius Game Reserve (O.F.S.), Rooipoort Estates (Kimberley, C.P.), and Setlagodi (C.P.) (Penzhorn 1971). Only three have survived since 1971 and they are not reproducing (National Parks Board of Trustees Annual Reports 46-49).

Damaliscus dorcas phillipsi Harper, 1939 Blesbok

Reintroduced from the Mountain Zebra National Park, Willem Pretorius Game Reserve (O.F.S.), Van Riebeeck Nature Reserve (Pretoria, Tvl.), Kestell (O.F.S.), Petrus Steyn (O.F.S.), Pietersburg (Tvl.), and Nduli National Reserve (Umtata, Transkei) (Penzhorn 1971). The population has settled down very well and is rapidly expanding (National Parks Board of Trustees Annual Reports 46-49). 
Reintroduced from the Willem Pretorius Game Reserve (O.F.S.), Odendaalsrus (O.F.S.), and Makwassie (Tvl.) (Penzhorn 1971). The population is viable and expanding rapidly (National Parks Board of Trustees Annual Reports 46-49).

\section{Antidorcas marsupialis Zimmermann, 1780 Springbok}

Reintroduced from the Bontebok National Park, Kalahari Gemsbok National Park, Mountain Zebra National Park, and Cookhouse (C.P.) Penzhorn 1971 ). The population is rapidly expanding (National Parks Board of Trustees Annual Reports 46-49).

The animals were reintroduced from the ranges of two subspecies, i.e. A. m. marsupialis from the Republic and A. m. hofmeyri Thomas, 1926 from the Kalahari Gemsbok National Park. The present Golden Gate population therefore could elucidate the hitherto unsettled state of subspeciation in this species.

\section{Ourebia ourebi Zimmermann, $1783 \quad$ Oribi \\ Oorbietjie}

Reintroduced from Greytown (Natal) (Penzhorn 1971). Births have been recorded (National Parks Board of Trustees Annual Report 48) and the population seems to be thriving.

\section{Raphicerus campestris Thunberg, $1811 \quad$ Steenbok}

The present day population is endemic (Penzhorn 1971), but its status is unknown.

\section{Pelea capreolus Forster, $1790 \quad$ Grey Rhebuck \\ Vaalribbok}

The existing population is also endemic (Penzhorn 1971), and appears to be stable although exact numbers are not known.

\section{Acknowledgements}

I wish to express my gratitude to the National Parks Board of Trustees for permission to collect material from the Golden Gate Highlands National Park, as well as for accommodation provided. My sincere thanks are due to $\mathrm{Mr} \mathrm{A}$. van Zyl, the ranger of the Park, for his assistance and advice. The late Dr Nico van der Merwe initiated the project, and later Dr G. de Graaff encouraged the completion of the work, and rendered advice and assistance whenever needed. This project was carried out and the results are published with the permission of the Director of the Transvaal Museum. 


\section{REFERENCES}

DAVIS, D. H. S. 1974. The distribution of some small southern African Mammals (Mammalia:Insectivora, Rodentia). Ann. Transvaal Mus. 29(9):135-184.

ELLERMAN, J. R., T. C. S. MORRISON-SCOTT and R. W. HAYMAN, 1953. Southern African Mammals 1758 to 1951: a Reclassification. Trustees of the British Museum.

LIEBENBERG, L. C. C. 1964. Die grotere soogdiere wat vroeër dae voorgekom het in die omgewing van die Golden Gate Hooglandpark. Koedoe $7: 99-104$.

LYNCH, C. D. 1975. The distribution of mammals in the Orange Free State, South Atrica. Navorsinge van die Nasionale Museum 3(6):109139.

PENZHORN, B. L. 1971. A summary of the re-introduction of ungulates into South African National Parks (to 31 December 1970). Koedoe 14:145-159.

PETTER, F. 1971 . Order Lagomorpha. In: MEESTER, J. and H. W. SETZER (eds.) 1971. The Mammals of Africa: an Identification Manual. Washington, D.C.: Smithsonian Institution Press.

ROBERTS, B. R. 1969. The vegetation of Golden Gate Highlands National Park. Koedoe 12:15-28.

VAN RENSBURG, A. P. J. 1968. Golden Gate-die geskiedenis van twee plase wat 'n Nasionale Park geword het. Koedoe 11:83-138. 